\title{
Teaching Management Based on Factor Analysis and Cluster Analysis
}

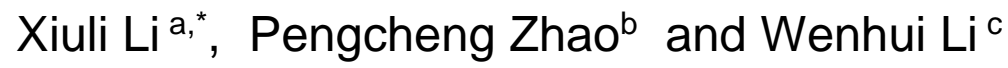 \\ School of Mathematics and Physics, Qingdao University of Science and Technology, \\ Qingdao, Shandong, China \\ alixiuli2007@aliyun.com, b2975064983@qq.com, c1466609016@qq.com
}

Keywords: Factor Analysis, Cluster Analysis.

\begin{abstract}
Based on the state of current education management, this paper uses factor analysis and cluster analysis to study students' performance, and then finds out main factors affecting the learning state of students by questionnaire so as to apply multivariate statistical analysis into effective teaching management according to those factors.
\end{abstract}

\section{Introduction}

Since the beginning of 1980s, western developed countries such as Britain and the United States have tried applying quality management theory to the field of education and have made some progress now. When it comes to 1990s, quality management system standard has been favored by scholars and universities both at home and abroad. Many universities have introduced quality management system standard to teaching work. The results of the teaching quality management are mainly embodied in students' academic achievements. This paper aims to find out the main factors influencing universities' teaching management, by analyzing 62 Mathematics and Applied Mathematics majors and 54 Information and Computing Science majors of grade 2011.

This paper applies two methods to analyze academic performance of students: one is to make factor analysis of students' scores; the other is to make cluster analysis. Such a measurement system can understand students' basic learning situation to a certain extent, so as to mobilize the initiative of students in order to improve teaching quality.

\section{Factor analysis of students' score}

Factor analysis is one typical methods in multivariate statistical analysis. It has been successfully applied in psychology, sociology, economics and other disciplines. Factor analysis is a technique for reducing dimension and simplifying data. It explores the basic structure of observed data by studying the internal dependence of many variables, and represents basic data structures with a few abstract variables. These abstract variables are called "factors" and can reflect the main information of original numerous variables. The original variables are observable, while the factors are generally unobservable potential variables.

The basic idea of factor analysis is to classify the observed variables. Those closely related are put together to form one group. As different groups are less connected, each group presents one structure, namely common factor. For the problem studied, we try to describe each component of the original observation with the sum of special factors and linear functions of the least number of so-called common factors.

SPSS software is used to make factor analysis of the academic performance of Mathematics and Applied Mathematics majors and Information and Computing Science majors of grade 2011 in 11 courses in the first school year. $X=\left(X_{1}, X_{2}, X_{3}, \cdots, X_{n}\right)^{T}$ is observable random vector, namely 116 students' score of 11 courses. $X_{i}=\left(\mathrm{X}_{i 1}, \mathrm{X}_{i 2}, \mathrm{X}_{i 3}, \cdots, \mathrm{X}_{i t}\right)$ represents score of student $i$ of course $\mathrm{j}(1 \leq j \leq t) . E(X)=u, D(X)=\Sigma . Y=\left(Y_{1}, Y_{2}, Y_{3}, \cdots, Y_{m}\right)^{T}(m<t)$ is unobservable random vector, 
$E(Y)=0, \mathrm{D}(Y)=\mathrm{I}_{m}$ (The variance of each vector is 1 and each of them is unrelated to each other). $\varepsilon=\left(\varepsilon_{1}, \varepsilon_{2}, \varepsilon_{3}, \cdots, \varepsilon_{n}\right)^{T}$ is unrelated to $\mathrm{Y}$. Random vector $\mathrm{X}$ satisfies the following model:

$$
X=u+A Y+\varepsilon
$$

Here $Y_{1}, Y_{2}, Y_{3}, \cdots, Y_{m}$ are called common factors, $\varepsilon_{1}, \varepsilon_{2}, \varepsilon_{3}, \cdots, \varepsilon_{n}$ are called special factors. Matrix $A=\left(a_{i j}\right)_{n \times m}$ in this model has the estimated coefficient, called factor loading matrix. Factor loading $a_{i j}$ is the correlation coefficient of variable $i$ and factor $j$, which demonstrates the importance of variable $i$ on factor $j$. Through factor analysis of data, 6 main factors are observed, which can be reflected in table 1.

Table 1. Factor score coefficient matrix

\begin{tabular}{|c|c|c|c|}
\hline \multirow{2}{*}{\multicolumn{2}{|c|}{ Courses }} & \multicolumn{2}{|c|}{ Common Factor } \\
\hline & & 1 & 2 \\
\hline 1 & English1 & -0.213 & 0.706 \\
\hline 2 & C Language1 & 0.073 & 0.160 \\
\hline 3 & $\begin{array}{c}\text { Mathematical } \\
\text { Analysis1 }\end{array}$ & 0.195 & -0.087 \\
\hline 4 & $\begin{array}{c}\text { Ideological and Moral } \\
\text { Cultivation }\end{array}$ & 0.119 & -0.048 \\
\hline 5 & Advanced Algebra1 & 0.204 & -0.106 \\
\hline 6 & Analytic Geometry & 0.178 & -0.049 \\
\hline 7 & English2 & -0.098 & 0.501 \\
\hline 8 & C Language2 & 0.136 & 0.072 \\
\hline 9 & $\begin{array}{l}\text { Mathematical } \\
\text { Analysis2 }\end{array}$ & 0.168 & -0.016 \\
\hline 10 & Advanced Algebra 2 & 0.159 & -0.014 \\
\hline 11 & Modern History & 0.159 & -0.129 \\
\hline
\end{tabular}

Figures in this table are correlation coefficients of common factor and original variable. The higher absolute value is, the closer their relation is. Common factor 1 is positively correlated to course 2 to course 6, called "logical reasoning ability" factor. Common factor 2 is positively correlated to English and C Language while negatively correlated to course 3 to course 6, called "language using ability" factor.

Table 2 is about the analysis of Total Variance Explained. As can be seen in this table, the first six factors can explain $86.221 \%$ variance. For students of this major, teachers should focus on students' learning attitude and students' learning in College English, C Language Programming, Mathematical Analysis, Advanced Algebra, Ideological and Moral Cultivation, Analytic Geometry and other basic courses.

Table 2. Total Variance Explained

\begin{tabular}{|c|c|c|c|c|c|c|c|}
\hline \multirow{2}{*}{ Courses } & \multicolumn{3}{|c|}{ Initial Eigenvalues } & \multicolumn{3}{|c|}{ Extraction Sums of Squared Loading } & \multirow{2}{*}{$\begin{array}{c}\text { Rotational } \\
\text { Sums of } \\
\text { Squared } \\
\text { Loading } \\
\text { Total }\end{array}$} \\
\hline & Total & $\begin{array}{c}\text { Percentage of } \\
\text { Variance }\end{array}$ & $\begin{array}{c}\text { Accumulat } \\
\text { ion } \%\end{array}$ & Total & $\begin{array}{c}\text { Percentage of } \\
\text { Variance }\end{array}$ & $\begin{array}{l}\text { Accumul } \\
\text { ation } \%\end{array}$ & \\
\hline 1 & 5.536 & 50.324 & 50.324 & 5.536 & 50.324 & 50.324 & 4.922 \\
\hline 2 & 1.082 & 9.839 & 60.163 & 1.082 & 9.839 & 60.163 & 1.695 \\
\hline 3 & .934 & 8.493 & 68.656 & & & & \\
\hline 4 & .715 & 6.501 & 75.157 & & & & \\
\hline
\end{tabular}




\begin{tabular}{|c|c|c|c|l|l|l|l|}
\hline 5 & .651 & 5.914 & 81.071 & & & & \\
\hline 6 & .566 & 5.149 & 86.221 & & & & \\
\hline 7 & .496 & 4.511 & 90.732 & & & & \\
\hline 8 & .326 & 2.962 & 93.694 & & & & \\
\hline 9 & .293 & 2.665 & 96.359 & & & & \\
\hline 10 & .220 & 1.999 & 98.359 & & & & \\
\hline 11 & .181 & 1.641 & 100.000 & & & & \\
\hline
\end{tabular}

\section{Cluster analysis of students' score}

"Birds of a feather flock together". To classify things is the starting point for people to know things, and also an important way for people to know the world. Cluster analysis is an analysis of how to quantify and classify samples (or variables). Generally, cluster analysis is divided into Q type and $\mathrm{R}$ type clustering. Q type is the classification of the samples, and $\mathrm{R}$ type is the classification of the variables.

The basic idea of system clustering is that the samples (or variables) with short distances are first clustered into groups, and then those with long distances are clustered into groups. With this process continuing, each sample (or variable) can finally be clustered into appropriate group. Here is the process: assuming that there are $n$ samples( or variables), the first step is to put each sample( or variables) into one group, so there is $n$ groups in all; the second step is to put two closer samples (or variables) into one group according to the formula of "distance", while other samples (or variables) still form one group by itself, so there is $n_{1}$ groups in all; the third step is to further clusters the closest two groups into one group, so there is $n_{2}$ groups in all; ....., the above steps are carried out, and all the samples (or variables) will be put into one group at the end. The whole classification system can be drawn as a dendrogram to clearly reflect the above system clustering process. Therefore, sometimes the system clustering is also called dendrogram analysis.

Cluster analysis is carried out through SPSS, taking 28 Information and Computing Science majors of class 1 as studying subject. In the result output window, we can see the cluster tree diagram, as shown in Figure 1. It can be clearly seen from Figure 1 that if 28 students are divided into two groups, then number 3, 4, 6, 17, 24, and 26 belong to one group, and the rest is another group; if 28 students are divided into three groups, then number 10, 15, 22, and 23 should be separated from the second group and form a new group, and so forth. 


$\begin{array}{cr}\text { C A S E } & 0 \\ \text { Label } & \text { Num } \\ & 11 \\ & 27 \\ & 18 \\ & 9 \\ & 13 \\ & 2 \\ & 19 \\ & 5 \\ & 20 \\ 14 \\ 21 \\ 7 \\ \\ 25 \\ 8 \\ 12 \\ 1 \\ 16 \\ 15 \\ 23 \\ 10 \\ \\ \\ \\ \\ \\ \\ 12 \\ 17 \\ 26 \\ 24 \\ 3 \\ 6 \\ 4\end{array}$

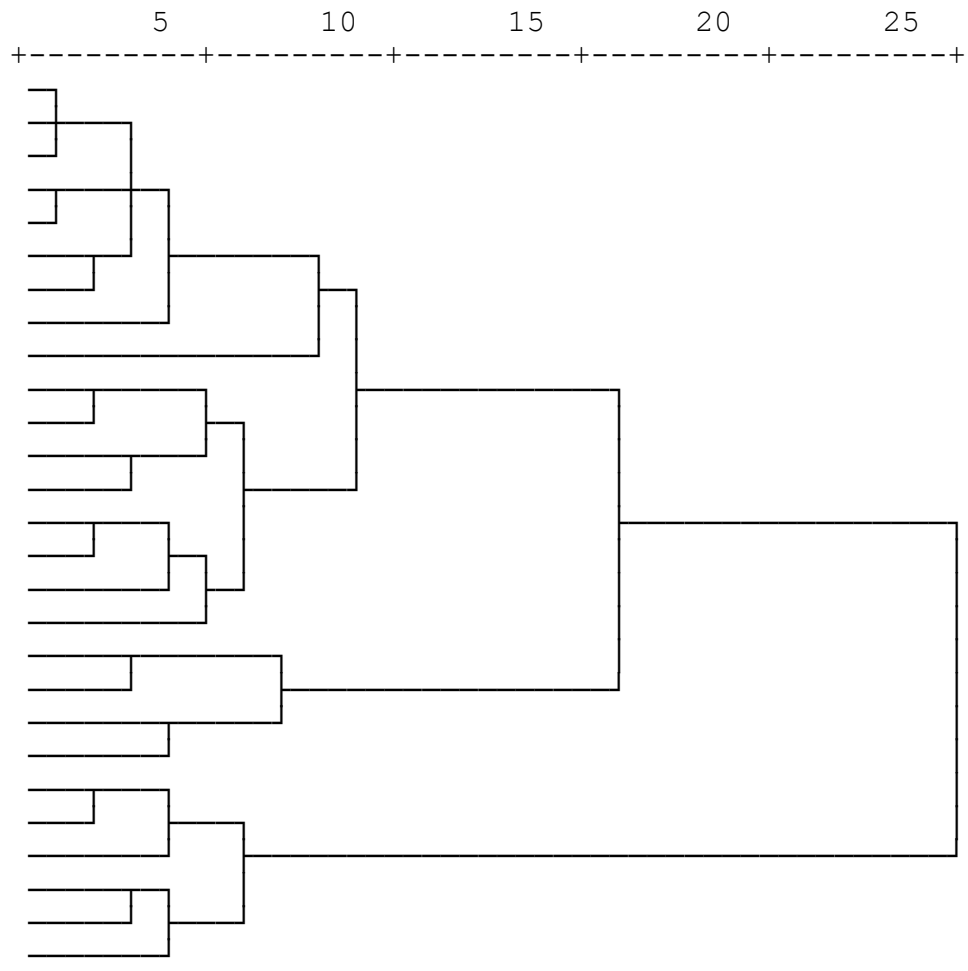

Figure 1

According to the above chart, 28 students are divided into three groups (the first group includes number $3,4,6,17,24$, and 26, the second group includes number 10,15, 22, and 15, and the rest are in one group. The result of score analysis are shown in Table 3.

Table 3. Analysis of Students' Academic Performance

\begin{tabular}{|c|c|c|c|}
\hline Classification of Students & Group 1 & Group 2 & Group 3 \\
\hline $\begin{array}{c}\text { Interval of Average Scores of } \\
\text { Various Courses }\end{array}$ & {$[85$, 100] } & {$[75,85]$} & $<75$ \\
\hline $\begin{array}{c}\text { Evaluation of Academic } \\
\text { Performance }\end{array}$ & Excellent & Good & Average \\
\hline
\end{tabular}

\section{The analysis of students' academic performance}

Through score analysis table, we divide students' achievements into three categories: excellent, good and average. Why are students' achievements so different? We conduct a questionnaire survey of 28 students in class 1 of grade 2011 in Information and Computing Science. The results are shown in Table 4.

Table 4. Questionnaire

\begin{tabular}{|c|c|c|c|c|}
\hline $\begin{array}{l}\text { Classification of } \\
\text { Academic } \\
\text { Performance }\end{array}$ & $\begin{array}{c}\text { Excellent } \\
(\text { No.3、4、6、 } \\
\text { 17、24、26) }\end{array}$ & $\begin{array}{c}\text { Good } \\
(\text { No.10、15、22、23) }\end{array}$ & $\begin{array}{r}\text { Average } \\
\text { (Other } \\
\text { Numbers) }\end{array}$ & Conclusion \\
\hline Interest in the Major & $\begin{array}{l}4 \text { of them are } \\
\text { fond of the } \\
\text { major while } 2 \\
\text { don't care }\end{array}$ & $\begin{array}{l}\text { 1of them is fond of the } \\
\text { major while } 3 \text { don't } \\
\text { care }\end{array}$ & $\begin{array}{l}4 \text { of them don't } \\
\text { care while another } \\
14 \text { dislike their } \\
\text { major }\end{array}$ & \multirow{2}{*}{$\begin{array}{l}\text { The students } \\
\text { with excellent } \\
\text { academic } \\
\text { performance } \\
\text { have a better } \\
\text { learning } \\
\text { attitude, listen } \\
\text { carefully on } \\
\text { class, and } \\
\text { review in time } \\
\text { after class. } \\
\text { The }\end{array}$} \\
\hline $\begin{array}{l}\text { Comprehension of } \\
\text { Teaching Content }\end{array}$ & $\begin{array}{l}\text { They can } \\
\text { easily grasp } \\
\text { the key points } \\
\text { and } \\
\text { understand } \\
\text { methods and } \\
\text { ideas of } \\
\text { teacher's }\end{array}$ & $\begin{array}{l}\text { They can basically } \\
\text { understand teaching } \\
\text { content as well as } \\
\text { methods and ideas of } \\
\text { teacher's explanation }\end{array}$ & $\begin{array}{l}\text { They seldom } \\
\text { listened to } \\
\text { teacher's } \\
\text { explanation in } \\
\text { class }\end{array}$ & \\
\hline
\end{tabular}




\begin{tabular}{|c|c|c|c|}
\hline & explanation & & \multirow{5}{*}{$\begin{array}{l}\text { phenomenon of } \\
\text { truancy is not } \\
\text { likely to occur in } \\
\text { excellent } \\
\text { students while } \\
\text { those with poor } \\
\text { performance } \\
\text { occasionally } \\
\text { skip classes, } \\
\text { which indicates } \\
\text { that students' } \\
\text { self-discipline is } \\
\text { significantly } \\
\text { different. } \\
\text { Teacher's } \\
\text { teaching attitude } \\
\text { is accepted by } \\
\text { most students. } \\
\end{array}$} \\
\hline Review after Class & $\begin{array}{l}\text { They basically review the day after class } \\
\text { or within } 1-2 \text { days }\end{array}$ & $\begin{array}{l}\text { They review } \\
\text { occasionally, or } \\
\text { even don't review } \\
\text { until examination }\end{array}$ & \\
\hline Self Learning & Often & Occasionally & \\
\hline $\begin{array}{l}\text { Frequency of } \\
\text { Skipping Classes }\end{array}$ & They hardly skip classes & $\begin{array}{l}\text { Occasionally, but } \\
\text { some of them } \\
\text { often skip classes }\end{array}$ & \\
\hline $\begin{array}{l}\text { Attitude towards } \\
\text { Teaching Method }\end{array}$ & $\begin{array}{l}85.2 \% \text { students were satisfied with teach } \\
\text { teachers, } 10.4 \% \text { students don't care, only } \\
\text { do not agree with teacher's teaching metl }\end{array}$ & $\begin{array}{l}\text { ig methods of } \\
1.4 \% \text { of the students } \\
\text { od. }\end{array}$ & \\
\hline
\end{tabular}

Through the analysis of the above questionnaire, we find out that the students' own factors are the most important factors that affect the universities' teaching quality management. However, it cannot be overlooked that the rationality and scientificity of curriculum system, and teachers' teaching attitude and methods in universities also influence students' learning. They directly affect personnel training quality and management standard in universities. Therefore, in order to improve the teaching quality management of universities, we need to start with main influencing factors and put forward some pertinent and effective suggestions and countermeasures.

\section{Acknowledgement}

This paper is one of the stage achievements of the high level teaching team of Qingdao University of Science and Technology (the teaching team of the basic course of mathematics for science and engineering students).

\section{References}

[1] Sang Feixiang and HU Wenxia, Factor Analysis on the effect of Interactive Teaching method in Colleges for nationalities: taking the course of "Public Economics" as an example, The Guide of Science \& Education, vol.11, pp. 115-117, 2017.

[2] Liu Wei, Chenyan, Wu Zhijiang, Wang Yongxiang, and Yang Si-ling, Based on Factor Analysis of Operations Research Teaching Graduate Student Satisfaction Analysis and Evaluation, Education Teaching Forum, vol.25, pp. 64-65, 2017.

[3] Wu Xi, Comprehensive Evaluation of Teaching quality of higher Education based on Factor Analysis, China Market, vol.47, pp. 94-95, 2016.

[4] XU Chun-jian and SHEN Liang-zhong, Cluster Analysis of Moodle Course Based on Teaching Effectiveness, Computer Knowledge and Technology, vol.13, pp. 115-117, 2017.

[5] LI Fu-ying and XIONG Wei-wei, Analysis and Evaluation of Network Teaching Platform Based on System Clustering Analysis, Value Engineering, vol. 3, pp. 167-169, 2008.

[6] Shaozhen Huang, The New Teaching Evaluation Based on Grey Clustering Analysis Application in the Open University Teaching, Electronic Science \& Technology, vol. 5, pp. 654-661, 2016. 